\title{
INHERITANCE STUDY OF YIELD COMPONENTS AND ESSENTIAL OIL CONSTITUENTS IN LINOOL TYPE BASIL
}

\author{
ESTUDO DA HERANÇA DO RENDIMENTO E CONSTITUINTES QUÍMICOS DO \\ ÓLEO ESSENCIAL DE MANJERICÃO TIPO LINALOL
}

\begin{abstract}
Mércia Freitas ALVES ${ }^{1}$; Arie Fitzgerald BLANK ${ }^{2 *}$; Daniela Aparecida de Castro NIZIO ${ }^{3}$; Maria de Fátima ARRIGONI-BLANK ${ }^{2}$; Péricles Barreto ALVES ${ }^{4}$; José Magno Queiroz LUZ

1. Pós-doutoranda em Agronomia da Universidade Federal de Uberlândia, Campus Umuarama, Uberlândia, MG, Brasil; 2. Professor do Departamento de Engenharia Agronômica, Universidade Federal de Sergipe, Av. Marechal Rondon s/n, São Cristóvão, Brasil. arie.blank@gmail.com; 3. Pós-doutoranda na Universidade Federal de Sergipe, Av. Marechal Rondon s/n, São Cristóvão, Brasil; 4. Professor do Departamento de Química, Universidade Federal de Sergipe, Av. Marechal Rondon s/n, São Cristóvão, Brasil;

5. Professor do Instituto de Ciências Agrárias, Universidade Federal de Uberlândia, Campus Umuarama, Uberlândia,MG, Brasil.
\end{abstract}

\begin{abstract}
The aim of this study was to conduct an inheritance study for the agronomic and chemical characteristics of basil (Ocimum basilicum L.) hybrid 'Genovese' $\mathrm{x}$ 'Maria Bonita'. $\mathrm{F}_{1}$ seeds were obtained from a cross of $\mathrm{P}_{1}$ (Genovese) x $\mathrm{P}_{2}$ (Maria Bonita). $\mathrm{F}_{2}$ seeds were obtained from selfing five $\mathrm{F}_{1}$ plants. In this experiment, a randomized block design with three replications was used. Each replication consisted of four treatments (generations). Seven plants from each $\mathrm{P}_{1}, \mathrm{P}_{2}$ and $\mathrm{F}_{1}$ generation and 21 plants from the $\mathrm{F}_{2}$ generation were grown for each replication. The following characteristics were evaluated at full bloom: plant height, leaf dry weight, essential oil content and yield in the leaves and the main essential oil chemical constituent concentrations in each plant. The characteristics plant height, essential oil yield and linalool content are controlled by more than one major gene, and these genes present additive and dominant effects. High heritability was observed for the characteristics plant height, leaf dry weight and content of linalool and 1,8-cineole. The hybrid 'Genovese' $\mathrm{x}$ 'Maria Bonita' presented a plant height and dry leaf weight heterosis of $32.31 \%$ and $131.54 \%$, respectively.
\end{abstract}

KEYWORDS: Ocimum basilicum. Volatile oil. Major compounds. Heritability.

\section{INTRODUCTION}

Basil (Ocimum basilicum) is a member of the Lamiaceae family and belongs to a group of plants that produce essential oils rich in chemical constituents. These essential oils have been researched and have already identified more than 200 chemical components (CHANG et al., 2008). There is a variability of the chemical composition, since different chemotypes have been found in several regions of the world (HASSANPOURAGHDAM et al., 2010), being classified according to their aroma in categories such as sweet, lemon, cinnamon, camphor, anise and clove (COSTA et al., 2014).

Knowledge about genetic variability and the extent to which it is caused by genetic differences between genotypes is necessary to achieve efficient genetic improvement programs. This ability consists of clearly defining the characters to be improved, distinguishing and planning the best crosses between the available genotypes, and choosing the best strategy of population management, so that continuous gains are maintained with the selection (RAMALHO et al., 2012).

Therefore, the use of genetic and phenotypic parameters such as heritability, genetic correlation coefficient and the implications of the environmental effects on these estimates are crucial for the character-based breeding program, such as dry mass, reflected in the genotype $\mathrm{x}$ environment interaction. The estimation of these parameters is one of the best ways to evaluate the genetic potential of germplasm, as well as to increase the efficiency of breeding methods (BLANK et al., 2010).

As for heritability, it is essential that it be as authentic as possible, because of its importance in predicting the genetic gains of a character. In the present study, it was found that the number of years of experimentation was higher than the number of years of experimentation (FERRÃO et al., 2008).

Observed additive and non-additive gene effects for general and specific basil combination capacities. In addition, these authors observed positive values for heterosis when the evaluated hybrid trait was higher than the average from the parents and negative values when the trait was lower (BLANK et al., 2012).

Knowledge regarding existing genetic variability is based on genetic parameters, such as heritability, genetic correlation coefficients and the implications of environmental effects on these estimates, and this knowledge reflects the genotype 
$\mathrm{x}$ environment interaction. In addition, this interaction is important for any genetic improvement program because it shows the trait's genetic control, which is important for establishing selection strategies (BLANK et al., 2010).

The estimates of genetic parameters are important in the targeting of breeding programs, since they and the selective process and serve as a theoretical reference to support commercial material recommendations (MAIA et al., 2009). The present study aimed to evaluate the inheritance of agronomic and chemical traits in the basil (Ocimum basilicum L.) 'Genovese' x 'Maria Bonita' hybrid.

\section{MATERIAL AND METHODS}

Plant material: The experiment was conducted between 10/11/2011 and 12/11/2011 in the field at the "Campus Rural da UFS" Research Farm in the São Cristóvão municipality, Sergipe, Brazil. The treatments included the $\mathrm{P}_{1}$ (Genovese), $\mathrm{P}_{2}$ (Maria Bonita), $\mathrm{F}_{1}$ ('Genovese' $\mathrm{x}$ 'Maria Bonita'), and $\mathrm{F}_{2}$ generations. To perform hybridization, inflorescences were selected and protected with paper bags to serve as female ('Genovese') and male ('Maria Bonita') parents, and were marked with wool yarn. Every morning (07:00 - 09:00 am), crosses were performed, emasculating the selected female flowers ('Genovese') of the previous day, and then collecting selected flowers ('Maria Bonita') of the previous day, which were touched (pollen) against the stigmas of the emasculated flowers of 'Genovese'. After hand pollination, the inflorescences were protected with paper bags (BLANK et al., 2012). The seeds were sown in 128cell expanded polystyrene trays that contained coconut dust, cattle manure and soil at a 1:1:1 ratio. When the seedlings developed three pairs of leaves, they were planted $0.60 \times 0.50 \mathrm{~m}$ apart.

A randomized block experimental design with three replications was used. Seven plants from each $\mathrm{P}_{1}, \mathrm{P}_{2}$ and $\mathrm{F}_{1}$ generation and 21 plants from the $\mathrm{F}_{2}$ generation were grown for each replication.

After 80 days of implantation of the experiment we evaluated plant height and dry weight of leaves.

Essential oil extraction and analysis: The essential oils were extracted by hydrodistillation in a Clevenger apparatus. Each sample consisted of the dried leaves of each plant, which were distilled for 140 minutes (EHLERT et al., 2006).

The chemical compositions of the essential oils were determined using a gas chromatograph coupled to a mass spectrometer (GC-MS) (Shimadzu, model QP 5050A) that was equipped with an AOC-20i auto injector (Shimadzu) and a fused-silica capillary column (5\%-phenyl-95\%dimethylpolysiloxane, $30 \mathrm{~m}$ x $0.25 \mathrm{~mm}$ id., $0.25 \mu \mathrm{m}$ film, J\&W Scientific). Helium was used as the carrier gas at a flow rate of $1.2 \mathrm{~mL} / \mathrm{min}$. The temperature program was as follows: it was initially $50^{\circ} \mathrm{C}$ for $1.5 \mathrm{~min}$, increased to $200^{\circ} \mathrm{C}$ at $4^{\circ} \mathrm{C} / \mathrm{min}$, increased to $250^{\circ} \mathrm{C}$ at $15^{\circ} \mathrm{C} / \mathrm{min}$ and maintained at $250^{\circ} \mathrm{C}$ for $5 \mathrm{~min}$. The injector temperature was $250^{\circ} \mathrm{C}$, and the detector (or interface) temperature was $280^{\circ} \mathrm{C}$. The injection volume of ethyl acetate was $0.5 \mu \mathrm{L}$, the partition rate of the injected volume was $1: 87$, and the column pressure was $64.20 \mathrm{kPa}$. The mass spectrometer conditions were as follows: an ionic capture detector impact energy of $70 \mathrm{eV}$ and a scanning speed of $0.85 \mathrm{scans} / \mathrm{s}$ from 40 to 550 Da.

Quantitative analyses of the chemical constituents were performed using flame ionization gas chromatography (FID) with a Shimadzu GC17A (Shimadzu Corporation, Kyoto, Japan). A ZB5MS capillary column (5\% phenyl-arylene-95\%dimethylpolysiloxane) fused with a silica capillary column $(30 \mathrm{~m} \mathrm{x} 0.25 \mathrm{~mm}$ i.d. $\times 0.25 \mu \mathrm{m}$ film thickness) from Phenomenex (Torrance, CA, USA) was used under the same conditions as those listed above for GC-MS. The quantity of each constituent was estimated by area normalization (\%). Compound concentrations were calculated from the GC peak areas and were arranged in the order of GC elution.

The essential oil components were identified by comparing their mass spectra with the spectra data available in the equipment database (NIST05 and WILEY8). In addition, the measured retention indices were compared to those in the literature (ADAMS 2007). The relative retention indices (RRI) were determined using the equation and with a homologous $n$-alkane $\left(\mathrm{C}_{8}-\mathrm{C}_{18}\right)$ series injected under the chromatography conditions described above (VAN DEN DOOL; KRATZ, 1963).

Statistical analyses: Using the plant height, leaf dry weight, essential oil content and yield and the major cultivar constituents, the genetic and phenotypic parameters and the number of genes were estimated with the GENES (Computer Application for Genetics and Statistics) software, version 2006.4.1 (CRUZ 2006). From the expected mean squares, the genetic $\left(\sigma^{2}\right)$, environmental $\left(\sigma^{2}{ }_{E}\right)$ and phenotypic $\left(\sigma_{F 2}^{2}\right)$ variance components, the broad-sense heritability $\left(\mathrm{h}^{2}\right)$, the heterosis $(\mathrm{H})$, the average degree of dominance (ADD) and the number of genes (n) were estimated with Wright's equation. 


\section{RESULTS AND DISCUSSION}

The $F_{1}$ and $F_{2}$ mean values were increased relative to the parental plant height, leaf dry weight and inflorescence and linalool content means (Table 1).

For the 'Genovese' x 'Maria Bonita' cross, genetic variance accounted for most of the phenotypic variance for the leaf dry weight. However, the plant height, essential oil content and yield and the linalool, geraniol and 1,8-cineole contents varied with environmental effects, which represented the majority of the phenotypic variance for all studied traits (Table 1).

Table 1. Estimation of genetic and phenotypic parameters for plant height, leaf dry weight, and the content and yield of the essential oils linalool, geraniol and 1,8-cineole.

\begin{tabular}{|c|c|c|c|c|c|c|c|}
\hline Parameter & $\begin{array}{l}\text { Plant height } \\
\text { (cm) }\end{array}$ & $\begin{array}{l}\text { Leaf } \\
\text { weight }(\mathrm{g})\end{array}$ & $\begin{array}{l}\text { dry Essential } \\
(\%)\end{array}$ & $\begin{array}{l}\text { oil Essential } \\
\text { (ml/plant) }\end{array}$ & $\begin{array}{l}\text { oil Linalool } \\
(\%)\end{array}$ & $\begin{array}{l}\text { Geraniol } \\
(\%)\end{array}$ & $\begin{array}{l}1,8 \text {-cineole } \\
(\%)\end{array}$ \\
\hline $\mathrm{P}_{1}$ (Genovese) & 44.19 & 13.66 & 3.27 & 0.40 & 77.85 & 17.69 & 5.13 \\
\hline $\begin{array}{ll}\mathrm{P}_{2} & \text { (Maria } \\
\text { Bonita) } & \end{array}$ & 47.64 & 38.39 & 1.24 & 0.40 & 64.92 & 18.09 & 12.92 \\
\hline $\mathrm{F}_{1}$ & 78.22 & 157.56 & 3.12 & 5.01 & 63.54 & 1.35 & 4.41 \\
\hline $\mathrm{F}_{2}$ & 56.53 & 40.66 & 0.75 & 0.31 & 52.99 & 2.04 & 8.35 \\
\hline$\overline{\sigma_{\mathrm{P} 1}^{2}}$ & 273.14 & 85.45 & 0.66 & 0.03 & 35.24 & 16.97 & 0.24 \\
\hline$\sigma_{\mathrm{P} 2}^{2}$ & 66.24 & 365.62 & 0.93 & 0.09 & 3.87 & 0.00 & 0.44 \\
\hline$\sigma_{\mathrm{F} 1}^{2}$ & 166.13 & 227.04 & 0.71 & 10.21 & 20.47 & 0.06 & 0.31 \\
\hline$\sigma_{\mathrm{F} 2}^{2}$ & 280.89 & 342.58 & 0.10 & 0.09 & 46.77 & 1.03 & 2.73 \\
\hline$\sigma_{G}^{2}$ & 111.20 & 617.04 & -0.69 & 0.03 & 27.21 & -7.46 & 0.34 \\
\hline$\sigma_{\mathrm{E}}^{2}$ & 169.69 & 225.54 & 0.79 & 0.06 & 19.56 & 8.48 & 2.39 \\
\hline $\mathrm{h}^{2}(\%)$ & 39.59 & 73.23 & -673.85 & 33.55 & 58.19 & -726.98 & 87.41 \\
\hline $\mathrm{H}(\%)$ & 32.31 & 131.54 & 0.86 & 4.62 & -7.85 & -7.50 & -4.62 \\
\hline $\mathrm{N}$ & 3.16 & 1.48 & -0.28 & 3.62 & 3.41 & -0.11 & 2.19 \\
\hline $\mathrm{ADD}$ & -18.75 & -10.64 & 0.85 & -1.94 & -1.21 & -0.85 & 1.19 \\
\hline
\end{tabular}

$\mathrm{P}_{1}=$ Genovese mean; $\mathrm{P}_{2}=$ Maria Bonita mean; $\mathrm{F}_{1}=\mathrm{F} 1$ (Genovese $\mathrm{x}$ Maria Bonita) mean; $\mathrm{F}_{2}=\mathrm{F}_{2}$ (Genovese $\mathrm{x}$ Maria Bonita) mean; $\sigma^{2} F_{2}$ = phenotypic variance; $\mathrm{H}=$ heterosis; $\sigma_{G}^{2}=$ genetic variance; $\sigma_{E}^{2}=$ environmental variance; $\mathrm{h}^{2}=$ heritability; $\mathrm{n}=$ number of genes and $\mathrm{ADD}=$ average degree of dominance.

The superiority of environmental variance relative to the phenotypic variance was observed in two traits and resulted in negative heritability estimates for essential oil and geraniol content. Reported that many authors consider negative heritability to equal zero. It is therefore the choice of the researcher to assess the nature of the data and select the ideal formula. Nevertheless, the values observed for heritability in this study suggest that superior individuals may be obtained through selection, especially by using the traits plant height, leaf dry weight and 1,8-cineole and linalool (Table 1) content. These results are in agreement with those Reis at al. 2008, who estimated mean harvest heritability values (considering cuts and sites) of $56.9 \%$ for plant height and of $58.8 \%$ for dry matter yield. However, our results disagreed with those Abreu et al. 2009 who studied Jatropha accessions and observed low broad-sense heritability (5.9\%) for plant height. This finding indicated that caution should be taken when selecting for this trait because the environment strongly influences the phenotypic expression of adaptive traits.
The different heritability values that were obtained in the present study confirmed that heritability is not only a characteristic feature, but depends on the genetic variation of the population and the environmental variances that individuals are subject to. Inheritability is a genetic parameter of great importance to the plant breeder, allowing an estimation of part of the inheritable phenotypic variance, genetic gain estimation, and a choice of selection methods to be applied. A heritability can be estimated through the measure of similarity between father and child, and also by components of variance, being genetic portion in the broad sense and in the restricted sense (COSTA et al., 2008). The knowledge of the associative behavior and of the existing correlations between desirable agronomic characters allowed to identify characters that are users in the selection, favoring another in an indirect way, that is, indicates how a selection for a given character influenced the expression of other characters, mainly for the quantitative characters of the low Heritability (ALMEIDA et al., 2010, RODRIGUES et al., 2013, SILVA et al., 2009). 
The mean heterosis values were $32.31 \%$, $131.54 \%, 0.86 \%, 4.62 \%,-7.85 \%,-7.50 \%$ and $4.62 \%$ for plant height, leaf dry mass, essential oil content, essential oil yield, linalool content, geraniol content and 1,8-cineole content (Table 1), respectively. These results suggested the presence of hybrid vigor for the plant height and leaf dry weight traits. The manifestation of heterosis generally depends on the genetic divergence between parental varieties. The presence of high heterosis becomes even more important when the parents (lineages) are productive, since high heterosis values are not always synonymous with high productivity (QUARTIEIRO, et al., 2014).

The heterosis or the hybrid vigor achieved through hybridization is expected to influence plant height and leaf dry weight, and these impacts allow for significant genetic gains during the selection process.

The magnitude of the mean degree of dominance (Table 1) revealed the existence of partial dominance for essential oil and 1,8-cineole content. The positive value for this estimate suggests that the dominance occurred through greater phenotypic manifestation of the trait.

Three genes controlled plant height, essential oil yield and linalool content (Table 1), and similar results were obtained Lopes et al. 2003, for the grain size trait and Rocha et al. 2009, for the peduncle size trait. This estimate is therefore useful as an indicator of polygenic nature and for obtaining favorable plant height, essential oil yield and linalool content genotypes. Few genes, low environmental influence and a high proportion of additive variance in the genetic variance expression may better facilitate genetic improvement.

\section{CONCLUSION}

Plant height, essential oil yield and linalool content are controlled by more than one major gene, and these genes present additive and dominant effects. High heritability was observed for plant height, leaf dry weight, and content of linalool and 1,8-cineole. The hybrid 'Genovese' $\mathrm{x}$ 'Maria Bonita' presented high heterosis for plant height and dry leaf weight.

\section{ACKNOWLEDGEMENTS}

The authors thank FAPITEC/SE, CNPq, CAPES and FAPEMIG for their financial support of this work.

RESUMO: O objetivo deste estudo foi realizar um estudo de herança para as características agronômicas e químicas de manjericão (Ocimum basilicum L.) híbrido 'Genovese' x 'Maria Bonita'. Sementes F1 foram obtidos a partir de um cruzamento de P1 (Genovese) x P2 (Maria Bonita). Sementes F2 foram obtidas a partir de autopolinização cinco plantas F1. Neste experimento, foi utilizado um delineamento em blocos casualizados com três repetições. Cada repetição foi constituída por quatro tratamentos (gerações). Sete plantas de cada P1, P2 e geração F1 e 21 plantas da F2 foram cultivadas para cada repetição. As seguintes características foram avaliadas em plena floração: altura da planta, folha seca, teor de óleo essencial e de rendimento nas folhas e as principais concentrações essenciais constituintes químicos do óleo em cada planta. A altura características da planta, o teor de óleo essencial e rendimento de linalol são controlados por mais do que um gene principal, e estes genes presentes efeitos aditivos e dominantes. Foi observada alta herdabilidade para as características altura da planta, folha de peso seco e conteúdo de linalol e 1,8-cineol. O híbrido 'Genovese' x 'Maria Bonita' apresentou altura de planta e peso da heterose seca de $32,31 \%$ e $131,54 \%$, respectivamente.

PALAVRAS-CHAVE: Ocimum basilicum. Óleo volátil. Principais compostos. Herdabilidade

\section{REFERENCES}

ABREU, F. B.; RESENDE, M. D. V. de; ANSELMO, J. L.; SATURNINO, H. M.; BRENHA, J. A. M.; FREITAS, F. B. Variabilidade genética entre acessos de pinhãomanso na fase juvenil. Magistra, Cruz das Almas, v. 21, n. 1, p. 36-40, jan./mar. 2009.

http://www.alice.cnptia.embrapa.br/handle/doc/309591

ADAMS, R. P. Identification of essential oil components by gas chromatography/mass spectroscopy. 4th ed., Allured: Carol Stream, 2007. 804p. 
ALMEIDA, R. D.; PELUZIO, J. M.; AFFERRI, F. S. Correlações fenotípicas, genotípicas e ambientais em soja cultivada sob condições várzea irrigada, sul do Tocantins. Bioscience Journal, Uberlândia, v. 26, n. 1, p. 9599, jan./fev. 2010. http://www.seer.ufu.br/index.php/biosciencejournal/article/view/7044/4670

BLANK, A. F; SOUZA, E. M; PAULA, J. W. A; ALVES, P. B. Comportamento fenotípico e genotípico de populações de manjericão. Horticultura Brasileira, v. 28, n. 3, p. 305-310, jul./set. 2010.

https://doi.org/10.1590/S0102-05362010000300011

BLANK, A. F.; ROSA, Y. R. S.; CARVALHO FILHO, J. L. S.; SANTOS, C. A.; ARRIGONI-BLANK, M. F.; NICULAU, E. S.; ALVES, P. B. A diallel study of yield components and essential oil constituents in basil (Ocimum basilicum L.). Industrial Crops and Products, v. 38, p. 93-98, jul. 2012.

https://doi.org/10.1016/j.indcrop.2012.01.015

CHANG, X.; ALDERSON, P. G.; WRIGHT, C. J. Solar irradiance level alters the growth of basil (Ocimum basilicum L.) and its content of volatile oils. Environmental and Experimental Botany, v. 63, n. 1-3, p. 216223, 2008. https://doi.org/10.1016/j.envexpbot.2007.10.017

COSTA, M. M.; DI MAURO, A. O.; UNÊDA-TREVISOLI, S. H.; ARRIEL, N. H. C.; BÁRBARO I. M.; DA SILVEIRA, G. D.; MUNIZ, F. R. S. Heritability estimation in early generations of two-way crosses in soybean. Bragantia, Campinas, v. 67, n. 1, p. 101-108, jan./mar. 2008.

http://dx.doi.org/10.1590/S0006-87052008000100012

COSTA, A. S. da; ARRIGONI-BLANK, M. F.; SILVA, M. A. A. P. da; ALVES, M. F.; SANTOS, D. A.; ALVES, P. B.; BLANK, A. F. The Impact of Hybridization on the Volatile and Sensorial Profile of Ocimum basilicum L. The Scientific World Journal, v. 2014, p. 1-7, 2014.

http://dx.doi.org/10.1155/2014/824594

CRUZ, C. D. Programa GENES: estatística experimental e matrizes. $1^{a}$ edição. Viçosa: Editora UFV, 1, 2006. 285p.

EHLERT, P. A. D.; BLANK, A. F.; ARRIGONI-BLANK, M. F.; PAULA, J. W. A.; CAMPOS, D. A.; ALVIANO, C. S. Tempo de hidrodestilação na extração de óleo essencial de sete espécies de plantas medicinais. Revista Brasileira de Plantas Medicinais, Botucatu, v. 8, n. 2, p. 79-80, 2006.

http://ri.ufs.br/handle/123456789/1548

QUARTIERO, A.; FARIA, M. V.; RESENDE, J. T. V.; FIGUEIREDO, A. S. T.; CAMARGO, L. K. P.; SANTOS, R. L.; KOBORI, R. F. Desempenho agronômico, heterose e estabilidade fenotípica de genótipos de cebola. Horticultura Brasileira, Vitória da Conquista, v. 32, n. 3, p. 259-266, jul./set, 2014.

http://dx.doi.org/10.1590/S0102-05362014000300004

FERRÃO, R. G.; CRUZ, C. D.; FERREIRA, A.; CECON, P. R.; FERRÃO, M. A. G.; FONSECA, A. F. A. da; CARNEIRO, P. C. S.; SILVA, M. F. da. Parâmetros genéticos em café Conilon. Pesquisa Agropecuária Brasileira, Brasília, v. 43, n. 1, p. 61-69, 2008. http://dx.doi.org/10.1590/S0100-204X2008000100009

HASSANPOURAGHDAM, M. B.; HASSANI, A.; SHALAMZARI, M. S. Menthone-and estragole-rich essential oil of cultivated Ocimum basilicum L. from Northwest Iran. Chemija, v. 21, n. 1, p. 59-62, 2010. https://www.researchgate.net/publication/233842773

LOPES, F. C. da C.; GOMES, R. L. F.; FREIRE FILHO, F. R. Genetic control of cowpea seed sizes. Scientia Agricola, Piracicaba, v. 60, n. 2, p. 315-318, abr./jun.2003. http://dx.doi.org/10.1590/S010390162003000200016

MAIA, M. C. C.; RESENDE, M. D. V.; PAIVA, J. R. de; CAVALCANTI, J. J. V.; BARROS, L. de M. B. Seleção simultânea para produção, adaptabilidade e estabilidade genotípicas em clones de cajueiro, via modelos mistos. Pesquisa Agropecuária Tropical, Goiânia, v. 39, p. 43-50, 2009. www.agro.ufg.br/pat 
RAMALHO, M. A. P.; SANTOS, E. M.; ZIMMERMANN, M. O. Genética quantitativa em plantas autógamas, aplicações ao melhoramento do feijoeiro. Editora UFG, Goiânia, 1993, 271p.

RAMALHO, M. A. P.; ABREU, Â. F. B.; SANTOS, J. B.; NUNES, J. A. R. Aplicações da genética quantitativa no melhoramento de plantas autógamas. Lavras: Universidade Federal de Lavras, 2012. 522 p.

REIS, M. C.; SOUZA SOBRINHO, F.; RAMALHO, M. A. P.; FERREIRA, D. F.; LEDO, F. J. S.; PEREIRA, A.V. Allohexaploid pearl millet $x$ elephantgrass population potential for a recurrent selection program.

Pesquisa Agropecuária Brasileira, Brasília, v. 43, n. 2, p. 195-199, fev. 2008.

http://dx.doi.org/10.1590/S0100-204X2008000200006

ROCHA, M. M.; CARVALHO, K. J. M.; FILHO, F. R. F.; LOPES, A. C. A.; GOMES, R. L. F.; SOUZA, I. S. Controle genético do comprimento do pedúnculo em feijão-caupi. Pesquisa Agropecuária Brasileira, Brasília, v. 44, n. 3, p. 270-275, mar. 2009. http://dx.doi.org/10.1590/S0100-204X2009000300008

RODRIGUES, J. I.; ARRUDA, K. M. A.; CRUZ, C. D.; PIOSEVAN N. D.; BARROS, E. G.; Moreira, M. A. Associação de marcadores microssatélites com teores de óleo e proteína em soja. Pesquisa Agropecuária Brasileira, Brasília, v. 48, n. 3, p. 255-262, mar. 2013. http://dx.doi.org/10.1590/S0100-204X2013000300003

SILVA, M. A.; SILVA, D. S.; ANDRADE, L. A.; W. B. LOPES, W. B.; Santos, G. R. A. Análise de trilha para caracteres morfológicos do feijão-bravo (Capparis flexuosa) no cariri paraibano. Archivos de Zootecnia, Córdoba, v. 58, n. 221, p. 121-124, mar. 2009. http://scielo.isciii.es/scielo.php?script=sci_arttext\&pid=S000405922009000100014\&lng=es.

VAN DEN DOOL, H.; KRATZ, P. D. A generalization of the retention index system including linear temperature programmed gas-liquid partition chromatography. J. Chromatogr. A, USA, v. 11, p. 463-471, aug. 1963. https://doi.org/10.1016/S0021-9673(01)80947-X 